\title{
Influence of prevailing weather parameters on population dynamics of fruit borer, Helicoverpa armigera (Hübner) on tomato in Haryana
}

\author{
SHIVANI KHOKHAR ${ }^{1}$, KRISHNA ROLANIA ${ }^{1}$, GAURAV SINGH ${ }^{1}$ and ANIL KUMAR ${ }^{2}$ \\ ${ }^{1}$ Department of Entomology, ${ }^{2}$ Department of Agricultural Meteorology, \\ CCS Haryana Agricultural University, Hisar-125004, Haryana, India \\ Corresponding authore-mail: shivanikhokhar08@yahoo.in
}

\begin{abstract}
A field experiment was conducted for two years (2016-17 and 2017-18) at Entomological Research Area, Department of Entomology, CCS Haryana Agricultural University, Hisar to ascertain the influence of various meteorological parameters on population fluctuations of Helicoverpa armigera on tomato. The maximum oviposition (4.60 eggs/ plant) was recorded during $15^{\text {th }}$ standard meteorological week (SMW) whereas larval population was at peak (4.91 larvae/ plant) during $16^{\text {th }}$ SMW. The larval population showed significant positive correlation with maximum temperature $\left(r=0.617^{*}\right)$ and highly significant negative correlation with morning $\left(r=-0.784^{* *}\right)$ as well as evening relative humidity $\left(r=-0.814^{* *}\right)$. Maximum eggs parasitization $\left(12.85 \%\right.$ ) by Trichogramma $\mathrm{sp}$. was recorded during $16^{\text {th }}$ SMW. These trichogrammatid parasitoids exhibited non-significant correlation with weather parameters and highly significant positive correlation $\left(r=0.976^{* *}\right)$ with egg counts of $H$. armigera. Multiple linear regression analysis showed that 77 per cent $\left(R^{2}=0.77\right)$ variability in larval population was accounted by weather parameters particularly maximum temperature, morning and evening relative humidity.
\end{abstract}

Keywords: Helicoverpa armigera, population, weather, parasitization, correlation

Tomato (Solanum lycopersicum), being the second most important vegetable crop, is cultivated throughout the world either outdoor or indoor for its edible fruits and fresh market consumption. The production and productivity of tomato crop is hampered by various biotic and abiotic factors among which, tomato fruit borer, Helicoverpa armigera Hübner is the major biotic stress (Consenza and Green, 1979). Being highly polyphagous in nature, it is reported to attack nearly 181 host plants and severally damage most of the economically important agricultural crops like cotton (Mukherjee and Bhowmik, 2009), tomato (Nebapure et al. 2018), pigeonpea (Deb and Bharpoda, 2017), chickpea (Sagar et al. 2017), oil seeds, cereals and vegetable crops (Dabhi et al. 2013). Studies on seasonal incidence in relation to abiotic factors are important for better understanding of pest scenario in different agroclimatic conditions. Before developing any management programme against insect-pests for particularagro ecosystem, it is necessary to have basic information on seasonal abundance of pest as well as their natural enemies in relation to meteorological parameters, as it helps to determine weak link in insect life cycle. Keeping this in view, we studied population dynamics of $H$. armigera and its relation with prevailing weather parameters.

\section{MATERIALS AND METHODS}

The experiment was conducted for two years (201617 and 2017-18) at Research Farm, Department of Entomology, CCS Haryana Agricultural University, Hisar to study the effect of weather parameters on the population dynamics of $H$. armigera and its potential parasitoids (Trichogramma spp.) in tomato. Crop was raised by following the recommended package of practices excluding the plant protection measures. Nursery of tomato $c v$. Selection-7 was procured from Department of Vegetable Science, CCS Haryana Agricultural University, Hisar and each year seedlings were transplanted in a flat bed of $100 \mathrm{~m}^{2}$ by adopting $60 \mathrm{~cm} \times 45 \mathrm{~cm}$ spacing in the second week of February. The whole bed was divided into 4 quadrates of 5 $\mathrm{m} \times 5 \mathrm{~m}$ each and pest population (eggs and larvae) was recorded at weekly interval starting from 15 days after transplanting. Eggs and larvae were counted during morning hours (6.00 to 8.00 AM) from randomly selected five plants per quadrate. Growing shoots and buds were carefully examined with hand lens for the presence of eggs and young larvae which were counted by "direct visual counting method". Leaves and flower buds were thoroughly examined for the presence of early instar larvae. To record egg parasitization by Trichogramma spp., 50 eggs of H. armigera 
Table 1: Population dynamics of H. armigera in relation to different weather parameters in tomato (pooled data of 2016 - 17

\begin{tabular}{|c|c|c|c|c|c|c|c|c|c|}
\hline \multirow[t]{2}{*}{ SMW } & \multicolumn{2}{|c|}{ H. armigera } & \multicolumn{2}{|c|}{ Temperature $\left({ }^{\circ} \mathrm{C}\right)$} & \multicolumn{2}{|c|}{ Relative humidity (\%) } & \multirow{2}{*}{$\begin{array}{l}\text { Rainfall } \\
\text { (mm) }\end{array}$} & \multirow{2}{*}{$\begin{array}{l}\text { Sunshine } \\
\text { (hours) }\end{array}$} & \multirow{2}{*}{$\begin{array}{l}\text { Wind } \\
\text { Velocity } \\
\left(\mathrm{km} \mathrm{h}^{-1}\right)\end{array}$} \\
\hline & $\begin{array}{l}\text { Eggs/ } \\
\text { plant }\end{array}$ & $\begin{array}{l}\text { Larvae/ } \\
\text { plant }\end{array}$ & Maximum & Minimum & Morning & Evening & & & \\
\hline 9 & 0.9 & 0.0 & 27.5 & 10.2 & 91 & 42 & 0.0 & 7.4 & 2.8 \\
\hline 10 & 1.1 & 0.5 & 27.2 & 10.1 & 87 & 40 & 0.5 & 7.4 & 3.6 \\
\hline 12 & 2.2 & 1.2 & 30.9 & 13.0 & 86 & 38 & 0.0 & 7.9 & 2.9 \\
\hline 13 & 2.8 & 2.4 & 35.5 & 15.2 & 79 & 29 & 0.0 & 8.7 & 3.2 \\
\hline 14 & 3.8 & 2.8 & 35.7 & 18.6 & 64 & 30 & 0.0 & 6.3 & 6.5 \\
\hline 15 & 4.6 & 3.0 & 35.4 & 16.0 & 65 & 27 & 1.0 & 8.6 & 4.6 \\
\hline 18 & 2.6 & 4.2 & 39.1 & 23.1 & 57 & 26 & 0.0 & 7.5 & 7.0 \\
\hline 19 & 1.3 & 3.2 & 40.9 & 23.6 & 56 & 23 & 0.1 & 7.8 & 5.9 \\
\hline 20 & 0.4 & 2.8 & 40.5 & 24.7 & 56 & 31 & 0.0 & 6.8 & 6.1 \\
\hline 21 & 0.2 & 1.3 & 41.7 & 24.3 & 52 & 25 & 0.0 & 8.4 & 4.6 \\
\hline 22 & 0.0 & 0.9 & 41.0 & 25.6 & 70 & 41 & 2.2 & 7.7 & 8.4 \\
\hline
\end{tabular}

Table 2: Correlation co-efficient between H. armigera population, egg parasitization and different weather parameters (pooled values of 2017 and 2018 )

\begin{tabular}{lcrc}
\hline Weather parameter & Eggs/plant & Larvae/plant & $\begin{array}{r}\text { Egg parasitization by } \\
\text { Trichogramma } \text { spp. }\end{array}$ \\
\hline Maximum temperature (Tmax) & 0.054 & $0.617^{*}$ & 0.077 \\
Minimum temperature ((Tmin) & -0.101 & 0.513 & -0.078 \\
Morning relative humidity (RH I) & -0.266 & $-0.784^{* *}$ & -0.257 \\
Evening relative humidity (RH II) & -0.487 & $-0.814^{* *}$ & -0.449 \\
Sunshine duration (BSS) & -0.207 & -0.267 & -0.166 \\
Rainfall & 0.313 & 0.256 & 0.260 \\
Wind velocity & -0.061 & 0.375 & -0.028 \\
\hline
\end{tabular}

* Correlation is significant at the 0.05 level of significance (Two-tailed)

;** Highly significant

were collected per week and kept at room temperature for incubation. After that, eggs were examined under the stereo zoom binocular microscope in Biocontrol laboratory, Department of Entomology for the presence of parasitization, if any. The weekly meteorological data on different weather parameters was procured from Agrometeorological

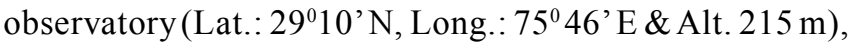
Department of Agrometeorology, CCS Haryana Agricultural University, Hisar. Data on pest population counts and all weather parameters were pooled for 2017 and 2018. Correlation co-efficient and multiple linear regressions of fruit borer population with different weather parameters was estimated using OPSTAT software (http://192.168.2.174/ opstat/default.asp) i.e. online platform for on-campus user.

\section{RESULTS AND DISCUSSION}

\section{Egg counts of $H$. armigera in relation to weather parameters}

Continuous monitoring of pest population revealed that oviposition by $H$. armigera was first noticed during $9^{\text {th }}$ SMW ( ${ }^{\text {st }}$ week of March) with 0.90 eggs per plant which increased afterwards and attained the peak (4.60 eggs/ 
Table 3: Fruit infestation by H. armigera in tomato at different pickings (pooled data of 2017 \& 2018)

\begin{tabular}{lcc}
\hline Fruit picking period & Fruit infestation (\%) (Number basis) & Fruit infestation (\%) (Weight basis) \\
\hline 18 SMW - First picking & 24.2 & 27.0 \\
19 SMW - Second picking & 28.4 & 32.7 \\
20 SMW - Third picking & 35.4 & 38.6 \\
21 SMW - Fourth picking & 36.6 & 38.7 \\
22 SMW - Fifth picking & 25.1 & 27.8 \\
Mean fruit infestation & 29.9 & 33.0 \\
\hline
\end{tabular}

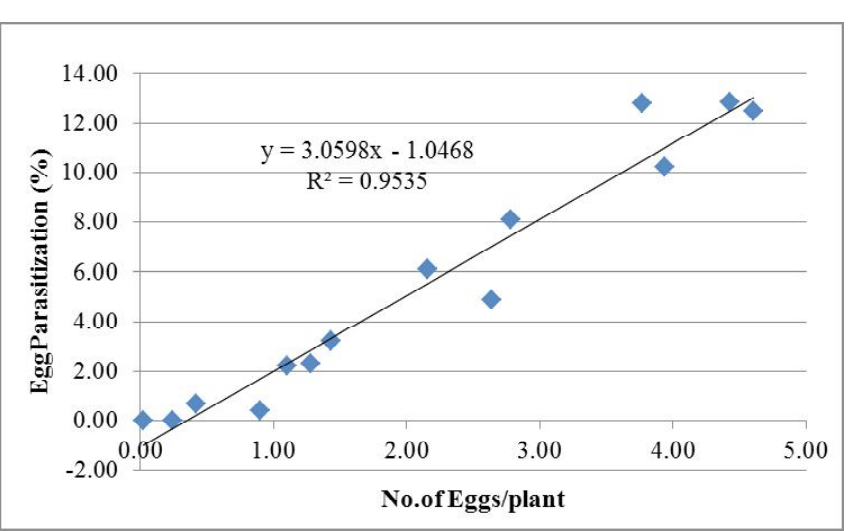

Fig. 1: Egg parasitization of $H$. armigera eggs by trichogramma spp. in relation to number of eggs of H. armigera

plant) during $15^{\text {th }}$ SMW (Table 1). Thereafter, a declining trend was recorded in egg laying which continued up to $22^{\text {nd }}$ SMW. Eggs of H. armigera were majorly parasitized by egg parasitoid, Trichogramma spp. under prevailing weather conditions. Trichogrammatids exhibited non- significant correlation with all meteorological parameters (Table 2). However, egg parasitizing behaviour of parasitoid was significantly positively correlated $\left(\mathrm{r}=0.976^{*}\right)$ with eggs counts of $H$. armigera indicating a proportional increase in eggs parasitization with increase in number of eggs laid (Fig. 1). Present findings were supported by Ballal and Singh (2003) who reported that per cent egg parasitization of $H$. armigera by Trichogramma spp. were positively correlated with number of eggs.

\section{Larval population in relation to weather factors:}

Commencement of larval population of $H$. armigera was first noticed during $9^{\text {th }}$ SMW ( $1^{\text {st }}$ week of March) which followed an increasing trend up to $16^{\text {th }} \mathrm{SMW}$ and then experienced a declining trend which continued up to $22^{\text {nd }}$ SMW (Table 1). Selvaraj and Bisht (2014) also reported that incidence of $H$. armigera started during February and March which attained peak infestation level during March and April (15 $5^{\text {th }}$ and $\left.16^{\text {th }} \mathrm{SMW}\right)$. The larval population was significantly and positively correlated with prevailing maximum temperature and non-significantly positively correlated with minimum temperature as revealed by the correlation analysis (Table 2). Antithetical to this, a highly significant negative relationship was observed between larval population and relative humidity (morning as well as evening) whereas the influence of all other weather factors was non-significant. Jat et al. (2017) reported significant positive association $\left(\mathrm{r}=0.518^{*}\right)$ between weather parameters and larval population of $H$. armigera on pigeonpea. The larvae of tomato fruit borer was observed feeding on leaves, buds, flower and fruits throughout the crop period ( $9^{\text {th }} \mathrm{SMW}$ to $22^{\text {nd }} \mathrm{SMW}$ ) but the infestation was more pronounced on fruits which resulted into direct loss in yield as recorded at each picking interval. Maximum fruit infestation was recorded during $3^{\text {rd }}$ picking (20 SMW i.e., $3^{\text {rd }}$ week of May) on both number and weight basis (Table 3). Similar fruit infestation by H. armigera was reported by Singh and Singh (1977).

\section{Regression analysis}

The multiple linear regression analysis of $H$. armigera larval population indicated that three important weather parameters viz., maximum temperature, morning relative humidity and evening relative humidity accounted 77 per cent variability in larval population Prasannakumar et al. (2011) reported that tomato fruit borer were influenced to an extent of 97 per cent by the combination of weather parameters viz., temperature (maximum and minimum), relative humidity (morning and evening) and rainfall.

$$
\begin{array}{r}
\operatorname{Larval}(\mathrm{Y})=9.01-0.035 * \operatorname{Tmax}-0.0 .39 * \mathrm{RH} \mathrm{I}-0.095 * \mathrm{RH} \mathrm{II} \\
\mathrm{R}^{2}=0.77 \text { ** }
\end{array}
$$

\section{CONCLUSIONS}

It is evident from the two year study that peak egg and larval population occurred during $15^{\text {th }}$ and $16^{\text {th }}$ SMW coinciding with vegetative and fruit development stage of the crop, respectively. The larval population had significant positive correlation with maximum temperature and negative 
correlation with relative humidity. The maximum temperature, morning and relative humidity altogether explained 77 per cent variability in pest population.

\section{ACKNOWLEDGEMENT}

We are thankful to Head, Department of Entomology, COA, CCS Haryana Agricultural University, Hisar for providing required support during these studies. We are also thankful to Department of Agrometeorology for providing the required weather data and technical support during course of work.

\section{REFERENCES}

Ballal, C.R. and Singh, S.P. (2003). The effectiveness of Trichogramma chilonis and T. brasiliense as parasitoids of Helicoverpa armigera on sunflower and redgram. Biocontrol Sci. Techn., 13:231-240.

Consenza, G.W. and Green, H.B. (1979). Behaviour of the tomato fruitworm, Heliothis zea on susceptible and resistant lines of processing tomatoes. Hortscience, 14:171-173.

Dabhi, M.V., Koshiya, D.J. and Korat, D.M. (2013). Effect of abiotic factors on population of aphid and damage by shoot and fruit borer in okra during summer and kharif season at Anand in Gujarat. J. Agrometeorol., 15(1):7174.

Deb, S. and Bharpoda, T.M. (2017). Impact of meteorological factors on population of major insect pests in tomato, Lycopersicon esculentum Mill. under middle Gujarat condition. J. Agrometeorol., 19(3):251-254.
Jat, B.L., Dahiya, K.K., Lal, R and Niwas, R. (2017). Effect of weather parameters on seasonal incidence of pod borer complex in pigeonpea. J. Agrometeorol., 19(3): 255258.

Mukherjee, A. and Bhowmik, P. (2009). Incidence of cotton bollworm (Helicoverpa armigera Hibner) in relation to meterological parameters in the saline zone of West Bengal. J. Agrometeorol., 11(2):169-171.

Nebapure, S.M., Sagar, D. and Chander, S. (2018). Population dynamics of insect pests on short duration pigeon pea in relation to weather parameters. J. Agrometeorol., 20(3):234-237.

Prasannakumar, N. R., Chakravarthy, A. K., Naveen, A.H. and Narasimhamurthy, T.N. (2011). Influence of weather parameters on pheromone traps catches of selected lepidopterous insects pests on vegetable crops. Curr. Biotic., 4(4):442-452.

Sagar, D., Nebapure, S.M. andChander, S. (2017). Development and validation of weather based prediction model for Helicoverpa armigera in chickpea. J. Agrometeorol., 19(4):328-333.

Selvaraj and Bisht, R.S. (2014). Seasonal incidence of Helicoverpa armigera (Hübner) on tomato at Pantnagar, Uttarakhand. Int. J. App. Basic. Med. Res., 12(3):351355.

Singh, H. and Singh, G. (1977). Biology studies on Heliothis armigera (Hub.) in Punjab, India. J. Entomol. Sci., 27:154-164. 